\title{
Dentist's Attitudes, Practice, and Barriers toward the Use of Rubber Dam during Operative and Endodontic Treatments: An Online Questionnaire Survey
}

\author{
Nezar Boreak ${ }^{1}$, Aeshah Hanbashi $^{2}$, Hala Otayf $^{3}$, Hamed Alshawkani $^{4}$, Mohammed Mashyakhy ${ }^{5}$, Hemant Chourasia ${ }^{6}$
}

\begin{abstract}
Aim and objective: To assess the attitude, practice, and barriers toward the use of rubber dam during endodontic and operative procedures among dentists in Jazan, Saudi Arabia.

Materials and methods: An online descriptive cross-sectional questionnaire survey was conducted among the dentists practicing in the Jazan region, Saudi Arabia. A total of 259 dentists participated in this study. Convenience sampling was used due to the limitation in the study duration and COVID-19 pandemic. The data collection were done online using a questionnaire designed at www.Kwiksurveys.com. The association between the independent variables and the responses to the questions was tested using the Chi-square test. Statistical significance was determined at $\alpha=0.05$.

Results: About $75 \%$ of participants mentioned that rubber dam was available in their clinic; however, only $71 \%$ had used it for their patients. Regarding the barriers that prevent the usage of rubber dam, $68 \%$ cited as financial reasons, $25 \%$ mentioned that they are not fully aware of how to use it, while $6 \%$ said that rubber dam was not available. A statistically significant association was found between training on rubber dam use, the working sector professional classification and experience, and using rubber dam for patients in the clinic. No statistically significant association was observed between rubber dam use and gender and place of education.

Conclusion: The participants had a favorable attitude toward rubber dam use. The training, operator experience, and workplace are favorably associated with rubber dam use. Increased cost, insufficient training, and non-availability of rubber dam were reported as the greatest barriers to regular usage.

Clinical significance: Most of the barriers reported for the non-usage of rubber dam are myths that have been propagated over time. The benefits of rubber dam use significantly outweigh the costs incurred.

Keywords: Dentists, Endodontics, Online survey, Questionnaire, Rubber dam.

World Journal of Dentistry (2021): 10.5005/jp-journals-10015-1840
\end{abstract}

\section{INTRODUCTION}

Operative and endodontic procedures are performed to treat tooth damage caused by dental caries or trauma. Tooth isolation during such procedures is paramount to prevent salivary contamination. This enables and ensures proper bonding of the restorative material to the tooth, thereby preventing re-infection and restoration failure. This also protects the patient and the dentists from unnecessary exposure to microorganisms. Poor bonding or secondary caries may compromise the longevity of the restoration. ${ }^{1-3}$

The rubber dam, first introduced by Barnum in 1864, is a useful process adjunct during operative and endodontic treatments and still the ideal tool for tooth isolation during dental therapeutic procedures. Rubber dam use has been documented to be essential for effective isolation in endodontic practice. The use of rubber dams during dental treatment procedures is believed to reduce microbial contamination and the potential for patients to swallow or inhale foreign bodies, ${ }^{4}$ thereby improving the efficiency of root canal treatment and addressing safety concerns. ${ }^{5}$ The quality assurance guidelines of the American Association of Endodontists state that cleaning, shaping, disinfection, and obturation of all canals are best accomplished using an aseptic technique with dental dam isolation whenever possible. Although rubber dam application is considered mandatory in root canal treatment, its use is not popular among dentists even though its more widespread use has been advocated. ${ }^{6,7}$ It is well-known that a rubber dam

\footnotetext{
${ }^{1,4-6}$ Department of Restorative Dental Science, College of Dentistry, Jazan University, Kingdom of Saudi Arabia

${ }^{2,3}$ College of Dentistry, Jazan University, Kingdom of Saudi Arabia
}

Corresponding Author: Nezar Boreak, Department of Restorative Dental Science, College of Dentistry, Jazan University, Kingdom of Saudi Arabia, Phone: +966 59901 6688, e-mail: nboraak@jazanu.edu.sa How to cite this article: Boreak N, Hanbashi A, Otayf H, et al. Dentist's Attitudes, Practice, and Barriers toward the Use of Rubber Dam during Operative and Endodontic Treatments: An Online Questionnaire Survey. World J Dent 2021;12(4):306-310.

Source of support: Nil

Conflict of interest: None

protects patients against the aspiration of instruments, prevents the laceration of soft tissue from rotary or hand instruments, improves accessibility and visibility, aids the retraction of soft tissue to some degree, and impedes cross-infection. ${ }^{3,8-10}$ The barriers to rubber dam use routinely by dentists are cited as patient acceptance, cost of rubber dam armamentarium, insufficient training, difficulty in use, the time required for its application, and financial constraints. ${ }^{7}$ Studies have been reported in other countries on rubber dam use among dentists and dental students..$^{2-4,11-15}$ There is a lack of knowledge regarding the use of rubber dam in our environment. Given the importance of rubber dam in endodontic treatment, it 
is imperative to determine the factors affecting its use to enable proper intervention to popularize its use. Hence, this study sought to determine the attitude and practice regarding the use of rubber dam during endodontic and operative procedures among dentists in Jazan, Saudi Arabia.

\section{Materials and Methods}

An online descriptive cross-sectional questionnaire survey was conducted among the dentists practicing in the Jazan region, Saudi Arabia, to achieve the purpose of this study. Ethical approval was obtained from the Institutional Review Board of Jazan University. All participants filled the informed consent form that contained information about the objectives of this study and their rights to withdraw from the study.

The sample size was calculated based on data on rubber dam usage from a previous study conducted in Saudi Arabia by Al Qarni in 2014. ${ }^{16}$ A sample size of 254 was required for the present study. The data collection were conducted from October 1, 2020, to December 31, 2020. The Saudi Commission for Health Specialties (SCFHS) database was used to identify the number of licensed dentists in Jazan, Saudi Arabia in September 2020. All licensed dentists practicing in Jazan who responded to the online survey were included in the study.

A total of 259 dentists participated in this study. Convenience sampling was used due to the limitation in the study duration and COVID-19 pandemic. The data collection were done using online questionnaires. A well-constructed questionnaire was developed through www.Kwiksurveys.com. The online survey link was posted on social media and an e-mail to the study participants and the responses were received through online survey submission.

A well-developed and pretested questionnaire was used as a tool for data collection. The questionnaire was tested for validity and reliability. Validity was tested for face validity and good comprehension was reported among respondents. Testretest reliability was assessed using the intraclass correlation coefficient with a score of 0.87 , indicating good reliability. The questionnaire covered two parts; part 1 included demographic information of participants, while part 2 covered variables related to study objectives. There were 14 closed-ended questions in the questionnaire.

The data were analyzed using IBM SPSS v. 24.0 (IBM Statistics, SPSS, Chicago, USA). The data were assessed for normality. The frequency and percentage of the responses were calculated. A chi-square test was employed to test the association between the independent variables and the responses to the questions. A $p$ value $<0.05$ was considered statistically significant.

\section{Results}

The present study was conducted among 259 dentists (males $=143$ and females $=116$ ) to assess the attitude and practice regarding the use of rubber dam during operative and endodontic practice using an online survey. The majority of the participants $(n=237,92 \%)$ were general practitioners, and the remaining were specialists. About $52 \%$ of participants worked at private clinics, while $48 \%$ worked at governmental clinics. More than half of the participants (52\%) were from Jazan University, 24\% graduated from other universities within Saudi Arabia, while only $12 \%$ were from universities outside of Saudi Arabia.
The response rate to the study was $79 \%$. The responses of the participants to the questionnaire are presented in Table 1. When questioned regarding training to use a rubber dam, most participants (95\%) had training on using a rubber dam during their study period, and $66 \%$ had been trained in using the rubber dam after graduation. Regarding the availability of rubber dams, about $75 \%$ of participants mentioned that rubber dam was available in their clinic; however, only $71 \%$ had used it for their patients. Only $42 \%$ of participants asked patients if they had an allergy to latex before using the rubber dam, and only $28 \%$ of patients rejected the use of rubber dam. Most of the participants had a favorable attitude toward the use of rubber dams. The majority of the participants (95\%) think that a rubber dam is important during endodontic treatment, and $92 \%$ mentioned that the most important use of the rubber dam is in the upper teeth. About $30 \%$ said that using the rubber dam is time-consuming. When questioned regarding the barriers that prevent the usage of rubber dam, $68 \%$ cited as financial reasons, $25 \%$ mentioned that they are not fully aware of how to use it, while $6 \%$ said that rubber dam was not available. About $76 \%$ of participants used rubber dam immediately after anesthesia, 12\% preparing the access cavity, $6 \%$ during the preparation of the root canals, while $6 \%$ during the obturation when asked about the stage of use. The respondents cited sterile gauze (21\%) and sterile cotton (3\%) as an alternative to rubber dams.

The association between the independent variables and the responses to the questionnaire was tested using the Chi-square test. A statistically significant association was found between training on rubber dam use and using rubber dam for patients in the clinic ( $p$ value $<0.05$ ) (Table 2 ). Additionally, a statistically significant association was found between rubber dam use and the working sector ( $p$ value $<0.05$ ), with a higher percentage $(76.6 \%)$ of dentists working in the government hospitals using it (Table 3 ). Also, there was a statistically significant association between rubber dam use and professional classification and experience $(p$ value $<0.05)$ with specialists (90.6\%) and those with a higher experience using rubber dam more often than their counterparts (Table 4). However, no statistically significant association was observed between rubber dam use and gender and place of education.

\section{Discussion}

The present study was conducted using an online questionnaire to assess the attitude, perceptions, and barriers toward the use of rubber dams among dentists in the Jazan region, Saudi Arabia.

In our study, we observed a reasonably good usage rate (71\%) of rubber dam among the study participants. This finding is in contrast with Unal et al., Peciuliene et al., Slaus and Bottenberg, Ibhawoh and Enabulele, Koshy and Chandler, Csinszka et al., Al Qarni, Sanghvi et al., and Abraham et al. who reported the use of rubber dam ranging from 5 to $57 \%$ among general practitioners. ${ }^{2,3,16-22}$ In the present study, no association was found between the place of education and rubber use. The literature has conflicting evidence in this regard. While a few authors found a significant difference in rubber dam use between dentists graduated from different universities, ${ }^{23}$ yet others found no effect of qualifying school on the frequency of use. ${ }^{20,24-27}$ A significant association was found in our study between the place of work with more practitioners in government sector routinely using rubber dam than those in private clinics. Similar results have been reported by Joynt et al., ${ }^{28}$ Koshy and $\mathrm{Chandler}^{20}$ who reported a higher usage among group practices rather than solo practice. Additionally, in the present 
Table 1: Responses of the study participants to the questions

\begin{tabular}{|c|c|c|c|c|}
\hline S.no. & & & Frequency & Percent \\
\hline \multirow[t]{3}{*}{1} & Have you ever been trained in using the rubber dam during the study? & Yes & 245 & 94.6 \\
\hline & & No & 14 & 5.4 \\
\hline & & Total & 259 & 100.0 \\
\hline \multirow[t]{4}{*}{2} & Have you ever been trained in using the rubber dam after graduation? & Yes & 172 & 66.4 \\
\hline & & No & 79 & 30.5 \\
\hline & & I trained but don't want to use it & 8 & 3.1 \\
\hline & & Total & 259 & 100.0 \\
\hline \multirow[t]{3}{*}{3} & Is rubber dam available in your clinic? & Yes & 195 & 75.3 \\
\hline & & No & 64 & 24.7 \\
\hline & & Total & 259 & 100.0 \\
\hline \multirow[t]{3}{*}{4} & Is rubber dam available in your clinic? & Yes & 195 & 75.3 \\
\hline & & No & 64 & 24.7 \\
\hline & & Total & 259 & 100.0 \\
\hline \multirow[t]{3}{*}{5} & Did you use a rubber dam for your patients? & Yes & 183 & 70.7 \\
\hline & & No & 76 & 29.3 \\
\hline & & Total & 259 & 100.0 \\
\hline \multirow[t]{3}{*}{6} & Did you ask the patient if he had an allergy to latex before & Yes & 109 & 42.1 \\
\hline & using the rubber dam? & No & 150 & 57.9 \\
\hline & & Total & 259 & 100.0 \\
\hline \multirow[t]{3}{*}{7} & Is the patient rejecting the rubber dam? & Yes & 72 & 27.8 \\
\hline & & No & 187 & 72.2 \\
\hline & & Total & 259 & 100.0 \\
\hline \multirow[t]{5}{*}{8} & Do you think the rubber dam is important in the endodontics treatment? & Yes & 247 & 95.4 \\
\hline & & No & 2 & .8 \\
\hline & & Probably & 9 & 3.5 \\
\hline & & Total & 258 & 99.6 \\
\hline & & Missing & 1 & .4 \\
\hline \multirow[t]{4}{*}{9} & The most important use of the rubber dam is? & In the upper teeth & 237 & 91.5 \\
\hline & & In the lower teeth & 21 & 8.1 \\
\hline & & Both of them & 1 & .4 \\
\hline & & Total & 259 & 100.0 \\
\hline \multirow[t]{3}{*}{10} & Do you think the rubber dam is difficult to use? & Yes & 62 & 23.9 \\
\hline & & No & 195 & 75.3 \\
\hline & & Total & 257 & 99.2 \\
\hline \multirow[t]{3}{*}{11} & Do you think the rubber dam wasting time? & Yes & 77 & 29.7 \\
\hline & & No & 182 & 70.3 \\
\hline & & Total & 259 & 100.0 \\
\hline \multirow[t]{5}{*}{12} & At what stage do you use the rubber dam? & Immediately after anesthesia & 198 & 76.4 \\
\hline & & While preparing the access cavity & 31 & 12.0 \\
\hline & & $\begin{array}{l}\text { During the preparation of the root } \\
\text { canals }\end{array}$ & 15 & 5.8 \\
\hline & & During the obturation & 15 & 5.8 \\
\hline & & Total & 259 & 100.0 \\
\hline \multirow[t]{3}{*}{13} & Barriers to the use of rubber dam & Financial problem & 176 & 68.0 \\
\hline & & Not available & 15 & 5.8 \\
\hline & & $\begin{array}{l}\text { I am not fully aware of how to } \\
\text { use it }\end{array}$ & 64 & 24.7 \\
\hline \multirow[t]{5}{*}{14} & What do you use during the endodontics treatment? & Do not use any dams & 186 & 71.8 \\
\hline & & Use sterile gauze & 54 & 20.8 \\
\hline & & Use sterile cotton & 7 & 2.7 \\
\hline & & Missing & 12 & 4.6 \\
\hline & & Total & 259 & 100.0 \\
\hline
\end{tabular}


Table 2: Association between using rubber dam and training

\begin{tabular}{|c|c|c|c|c|c|c|c|}
\hline & & & \multicolumn{3}{|c|}{ Training on dam use } & \multirow[b]{2}{*}{ Total } & \multirow[b]{2}{*}{$p$ value } \\
\hline & & & Yes & No & Trained but not use & & \\
\hline \multirow[t]{4}{*}{ Using rubber dam for patients in the clinic } & Yes & Count & 142 & 41 & 0 & 183 & 0.00 \\
\hline & & $\%$ within training & $82.6 \%$ & $51.9 \%$ & $0.0 \%$ & $70.7 \%$ & \\
\hline & No & Count & 30 & 38 & 8 & 76 & \\
\hline & & $\%$ within training & $17.4 \%$ & $48.1 \%$ & $100.0 \%$ & $29.3 \%$ & \\
\hline
\end{tabular}

Table 3: Association between using rubber dam and working sector

\begin{tabular}{|c|c|c|c|c|c|c|}
\hline & & & \multicolumn{2}{|c|}{ Sector } & \multirow[b]{2}{*}{ Total } & \multirow[b]{2}{*}{$p$ value } \\
\hline & & & Governmental & Private & & \\
\hline \multirow[t]{4}{*}{ Using rubber dam for patients in the clinic } & Yes & Count & 95 & 88 & 183 & 0.04 \\
\hline & & $\%$ within sector & $76.6 \%$ & $65.2 \%$ & $70.7 \%$ & \\
\hline & No & Count & 29 & 47 & 76 & \\
\hline & & $\%$ within sector & $23.4 \%$ & $34.8 \%$ & $29.3 \%$ & \\
\hline
\end{tabular}

Table 4: Association between using rubber dam and professional classification

\begin{tabular}{|c|c|c|c|c|c|c|}
\hline & & & \multicolumn{2}{|c|}{ Professional classification } & \multirow[b]{2}{*}{ Total } & \multirow[b]{2}{*}{$p$ value } \\
\hline & & & $\begin{array}{l}\text { General practitioner } \\
\text { (GP) }\end{array}$ & Specialist & & \\
\hline \multirow[t]{4}{*}{ Using rubber dam for patients in the clinic } & Yes & Count & 163 & 20 & 183 & 0.02 \\
\hline & & $\%$ within job classification & $68.8 \%$ & $90.9 \%$ & $70.7 \%$ & \\
\hline & No & Count & 74 & 2 & 76 & \\
\hline & & $\%$ within job classification & $31.2 \%$ & $9.1 \%$ & $29.3 \%$ & \\
\hline
\end{tabular}

study, a positive association was observed between training on rubber dam use and using rubber dam for patients in the clinic. Similar findings were reported by Joynt et al. ${ }^{28}$ We also observed that the years of experience positively affected rubber dam use with more experienced operators having a higher frequency of usage. We found many studies contradicting this finding and reported that the rubber dam use declined with age. There was no effect of gender on rubber dam use in our research which is supported by evidence from previous studies by Marshall and Page and Palmer et al. ${ }^{25,26}$

The barriers that prevent rubber dam usage in the present study were reported as financial reasons, lack of training and confidence to use, and non-availability of rubber dam in the clinic. Previous studies have also cited various reasons for the low usage of rubber dam by dental practitioners. The most widely quoted reasons include concerns regarding patient acceptance, increased application time, insufficient training and confidence, technique sensitivity, cost of rubber dam armamentarium, and other financial constraints. ${ }^{7}$ The participants in our research reported that $28 \%$ of patients rejected the use of rubber dam, which is also cited as the reason for lack of use by many practitioners in other papers. ${ }^{15,20,23,25,27}$ However, several other authors have quoted favorable patient reactions toward rubber dam..$^{29-31}$ The operator's positive attitude, training, competency in rubber dam use, and enhanced experience have known to improve patients' acceptance. ${ }^{29-31}$

Another reason cited by the participants for non-usage is lack of training. However, most of the participants accepted that they had received training on rubber dam placement in school. Therefore, the limited utilization rate of a rubber dam may be attributed to lack of regular use owing to poor proficiency instead of lack of knowledge or insufficient training. ${ }^{15}$ The increased cost is customarily quoted as a reason for the infrequent use of the rubber dam. ${ }^{4,20,25,27}$ Nonetheless, the rubber dam armamentarium has a high shelf-life when appropriately used. Additionally, the benefits of rubber dam use, in terms of infection control, medicolegal, and safety implications, outweigh the costs incurred. ${ }^{15}$

The recent COVID-19 pandemic outbreak has posed an incredible challenge to the patients and healthcare professionals, particularly dentists. The use of rubber dam isolation in endodontic procedures is essential as the high-speed rotary instruments produce a very high aerosol. This conduct significantly reduces patients' salivary fluids in the aerosols, thereby depreciating the microorganism suspension in the environment. ${ }^{32,33}$ Hence, rubber dam use during endodontic and operative procedures cannot be emphasized enough in the present times.

The limitations of the study are due to conducting an online survey the reliability of the opinion expressed by the participant is questionable. As convenience sampling was followed in the study, it may lack external validity.

\section{Conclusion}

It can be concluded from the present study that the study participants had a favorable attitude toward rubber dam use and deemed it important during endodontic procedures. The training in rubber dam placement, operator experience, and work in the public sector is favorably associated with rubber dam use. Increased cost, insufficient training, and non-availability of rubber dam were reported as the greatest barriers to regular usage. 


\section{Clinical Significance}

Rubber dam use significantly reduces the chance of salivary contamination, re-infection, and accidental aspiration of dental instruments and materials, thereby improving patient safety, increasing the longevity of the restorations, and protecting the dentists against medicolegal cases. Moreover, it significantly reduces aerosolization of patient's salivary fluids and contributes to keep dental office teams and patients safe and protected.

\section{References}

1. Wang $Y, L i C$, Yuan $H$, et al. Rubber dam isolation for restorative treatment in dental patients. Cochrane Database Syst Rev 2016;9(9):CD009858. DOI: 10.1002/14651858.CD009858.pub2.

2. Sanghvi AM, Nagda RJ, Raju PJ. A cross-sectional study on frequency of rubber dam usage among dentists practicing in Maharashtra. India Saudi Endod J 2018;8(1):39-43. DOI: 10.4103/sej.sej_92_16.

3. Ibhawoh LO, Enabulele JE. Rubber dam use during non-surgical endodontic treatment among a population of dentists in Edo State. Nig J Dent Res 2020;5(1):35-41.

4. Ahmed HM. Rubber dam application in endodontics: evidence and practice. Eur J Gen Dent 2015;4(3):161-162. DOI: 10.4103/22789626.163320.

5. Ahmed HM, Cohen S, Levy G, et al. Rubber dam application in endodontic practice: an update on critical educational and ethical dilemmas. Aust Dent J 2014;59(4):457-463. DOI: 10.1111/adj.12210.

6. Hedge MN, Hedge P, Hegde A. Rubber dam isolation for endodontic treatment in difficult clinical situations. J Dent Sci 2014;2:12-18.

7. Ahmad CA. Rubber dam usage for endodontic treatment: a review. Int Endod J 2009;42(11):963-972. DOI: 10.1111/j.1365-2591.2009.01623.x.

8. Cochran MA, Miller $\mathrm{CH}$, Sheldrake MA. The efficacy of the rubber dam as a barrier to the spread of micro-organisms during dental treatment. J Am Dent Assoc 1989;119(1):141-145. DOI: 10.14219/jada. archive.1989.0131.

9. Castellucci A. Tooth isolation-rubber dam. In: Textbook of endodontics, vol. I., IL Tridente 2004. pp. 226-243.

10. Weisman MI. Remedy for dental dam leakage problems. J Endod 1991;17(2):88-89. DOI: 10.1016/S0099-2399(06)81615-8.

11. Khan HR, Azam S, Qureshi B. Knowledge and attitude of house officers regarding rubber dam use. PODJ 2018;38(1):97-101.

12. Tanwir A, Amin M, Choudhry Z, et al. Knowledge, attitude and perception of dental fraternity towards practice of rubber dam. Pakistan Oral Dent J 2015;35(4):691-694.

13. Tanalp J, Kayatas M, Can ED, et al. Evaluation of senior dental students' general attitude towards the use of rubber dam: a survey among two dental schools. Sci World J 2014;2014:290101. DOI: $10.1155 / 2014 / 290101$.

14. Shashirekha G, Jena A, Maity $A B$, et al. Prevalence of rubber dam usage during endodontic procedure: a questionnaire survey. J Clin Diagnos Res: JCDR 2014;8(6):ZC01.

15. Lynch CD, McConnell R. Attitudes and use of rubber dam by Irish general dental practitioners. Int Endodon J 2007;40(6):427-432. DOI: 10.1111/j.1365-2591.2007.01212.x.
16. Al Qarni MA. A survey on usage of rubber dam during composite restorative procedures by general and specialist dental practitioners in Saudi Arabia. J Orofac Res 1970;3(1):1-4. Available from: https:// mansapublishers.com/index.php/jofr/article/view/1879.

17. Unal GC, Kaya BU, Tac AG, et al. Survey of attitudes, materials and methods preferred in root canal therapy by general dental practice in Turkey: Part 1. Eur J Dent 2012;6(4):376-384. DOI: 10.1055/s-00391698975.

18. Peciuliene V, Rimkuviene J, Aleksejuniene J, et al. Technical aspects of endodontic treatment procedures among Lithuanian general dental practitioners. Stomatologija 2010;12(2):42-50.

19. Slaus $G$, Bottenberg P. A survey of endodontic practice amongst Flemish dentists. Int Endod J 2002;35(9):759-767. DOI: 10.1046/j.13652591.2002.00564.x.

20. Koshy S, Chandler NP. Use of rubber dam and its association with other endodontic procedures in New Zealand. N Z Dent J 2002;98(431):1216.

21. Csinszka K, Monica M, Mihai P, et al. Prevalence of rubber dam usage among dental practitioners and final year students in tirgu mures: a questionnaire survey. Acta Marisien Seria Medica 2015;61(3):188-191. DOI: 10.1515/amma-2015-0059.

22. Abraham SB, Rahman B, Istarabadi A, et al. Attitudes towards use of rubber dam in private practices in the United Arab Emirates. Saudi Endod J 2012;2(3):142-146. DOI: 10.4103/1658-5984.112708.

23. Whitworth JM, Seccombe GV, Shoker K, et al. Use of rubber dam and irrigant selection in UK general dental practice. Int Endod J 2000;33(5):435-441. DOI: 10.1046/j.1365-2591.2000. 00329.x.

24. Mala $S$, Lynch CD, Burke FM, et al. Attitudes of final year dental students to the use of rubber dam. Int Endodon J 2009;42(7):632-638. DOI: 10.1111/j.1365-2591.2009.01569.x.

25. Marshall K, Page J. The use of rubber dam in the UK. A survey. Br Dent J 1990;169(9):286-291. DOI: 10.1038/sj.bdj.4807357.

26. Palmer NO, Ahmed M, Grieveson B. An investigation of current endodontic practice and training needs in primary care in the north west of England. Br Dent J 2009;206(11):E22. discussion 584-5 10.1038/ sj.bdj.2009.473.

27. Stewardson DA. Endodontics and new graduates: Part l, practice vs training. Eur J Prosthodont Restor Dent 2002;10(3):131-137.

28. Joynt RB, Davis EL, Schreier PH. Rubber dam usage among practicing dentists. Oper Dent 1989;14(4):176-181.

29. Gergely EJ. Desmond greer walker award. Rubber dam acceptance. Br Dent J 1989;167(7):249-252. DOI: 10.1038/sj.bdj.4806985.

30. Filipović J, Jukić S, Miletić I, et al. Patient's attitude to rubber dam use. Acta Stomatol Croat 2004;38:319-322.

31. Stewardson DA, McHugh ES. Patients' attitudes to rubber dam. Int Endod J 2002;35(10):812-819. DOI: 10.1046/j.1365-2591.2002. 00571.x.

32. Samaranayake LP, Reid J, Evans $D$. The efficacy of rubber dam isolation in reducing atmospheric bacterial contamination. ASDC J Dent Child 1989;56(6):442-444.

33. Seron MA, Strazzi-Sahyon HB, Banci HA, et al. The importance of rubber dam isolation in endodontics throughout COVID-19 outbreak. Braz Dent J 2020;31(6):567. DOI: 10.1590/0103-6440202003760. 